\title{
USE OF BENCHES WITH REFLECTIVE MATERIAL TO FAVOR PRODUCTION OF RUBBER TREE ROOTSTOCK SEEDLINGS
}

\author{
Edilson Costa ${ }^{*}$, Bruna L. B. da Silva ${ }^{1}$, Franciele K. O. M. Aguiar ${ }^{1}$, \\ Talita C. C. Pereira1, Flávio F. da S. Binotti ${ }^{1}$
}

\author{
${ }^{1 *}$ Corresponding author. Universidade Estadual de Mato Grosso do Sul/ Cassilândia - MS, Brasil. \\ E-mail: edilson.costa@uems.br | ORCID ID: http://orcid.org/0000-0002-4584-6611
}

\begin{abstract}
KEYWORDS
plant environment, clone GT1, Hevea brasiliensis, photosynthetically active radiation.
\end{abstract}

\begin{abstract}
Success in production of any perennial tree depends on the use of high-quality seedlings. This study aimed to evaluate cultivation benches with reflective material and protected environments for production of rubber tree rootstock seedlings. The experiments were conducted in two types of protected environments: $35 \%$ shading aluminized screen and $30 \%$ shading black screen. Cultivation benches with and without reflective material were tested inside the protected environments. A completely randomized design with 7 replications and 5 seedlings per plot was adopted for each environment, and the environments were compared by joint analysis. Solar radiation (global and photosynthetically active) was the most influencing micrometeorological factor on plant environment and plant growth differentiation. Regardless of the environment, the use of reflective material in cultivation bench had a positive effect on production of rubber rootstock seedling (clone GT1), providing seedlings with a robust root system and better quality. The use of reflective material also improved rubber tree rootstock seedlings (clone GT1) grown in the black screen environment.
\end{abstract}

\section{INTRODUCTION}

The use of protected environments aims to provide the best conditions for a suitable plant development, either for seedling or fully grown plants. Thus, Agriculture 4.0 has been increasingly applied to reduce human errors, always aiming at production and product safety in a precision planting environment (Costa et al., 2020a). Besides reducing sunlight direct incidence on plants by shading with a cover, the protected environment can favor microclimate conditions, protect against pests, and decrease evapotranspiration, strengthening seedlings. Studies have demonstrated that plant species interact differently when under certain shading levels, which can provide seedlings of different sizes (Costa et al., 2017; Cruz et al., 2016; Santos et al., 2016).

Adequate protected environments are needed to obtain high-quality rubber tree (Hevea brasiliensis) rootstocks, aiming at healthy grafting and good quality seedlings for field production. Some studies have shown production of better rubber tree rootstocks clone G1 by using $50 \%$ shading screen (Sombrite ${ }^{\circledR}$ and Aluminet ${ }^{\circledR}$ ) when compared to direct sunlight (Vieira et al., 2016). In turn, when covered with low-density polyethylene, agricultural greenhouses have shown better results than the former mentioned screens (Silva et al., 2020).

The use of reflective material in cultivation benches is a recent technique to reflect part of the photosynthetically active radiation (PAR) reaching the benches to plant leaves, increasing the amount of light energy available and thus improving its use in photosynthesis. This material proved to be efficient in production of jambolan seedlings, with better results under $30 \%$ shading (Salles et al., 2017). A positive effect was also observed for aluminum foil on cultivation benches of paricá (Schizolobium amazonicum) seedlings when associated with 42 and 50\% shading greenhouses (Mortate et al., 2019); the same was observed for papaya (Carica papaya) (Cabral et al., 2020).

When compared to faux sequin fabric, the use of mirrors on cultivation benches provided higher growth rates and shoot dry matters in passion fruit (Passiflora edulis Sims. f. flavicarpa Deg) (Santos et al., 2017) and baruzeiro (Dipteryx alata Vog) seedlings (Costa et al., 2020b).

${ }^{1}$ Universidade Estadual de Mato Grosso do Sul/ Cassilândia - MS, Brasil. 
Conversely, the use of aluminized screen (Aluminet®) on cultivation benches did not increase the quality of baruzeiro (Dipteryx alata Vog) (Costa et al., 2020c) or papaya (Carica papaya) seedlings (Cabral et al., 2020).

Formation pruning and use of reflective material on cultivation benches in peach tree production have proved to intensify the red color of fruit epidermis by $45 \%$, for the cultivar 'Eldorado' (Coutinho et al., 2005). In rubber tree seedlings and adult plants, the overlapping of leaves interferes with the use of solar radiation (Conforto et al., 2011); therefore, the absorption of radiation reflected from bench material in the leaf abaxial surface may help plant growth. According to Wang et al. (2004), lower leaves of melon seedlings have a significant reduction in photosynthetic capacity compared to upper leaves.

Given the above, this study aimed to evaluate the use of reflective material on cultivation benches for production of rubber tree rootstock seedlings in protected environments.

\section{MATERIAL AND METHODS}

The experiments were conducted at the State University of Mato Grosso do Sul-Cassilândia-MS (Brazil) from February to October 2018. They were carried out in two screened environments measuring $18.0 \mathrm{~m} \mathrm{x} 8.0 \mathrm{~m}$ x 3.5 $\mathrm{m}$, and closed at 45 degrees, namely: a) one agricultural screen with aluminized heat-reflective screen of $35 \%$ shading, and b) one agricultural screen of black monofilament screen of $30 \%$ shading.

In these protected environments, cultivation benches covered or not with a heat-reflective screen with $50 \%$ shading were tested. According to Köppen-Geiser climate classification, the local climate is tropical $(A w)$ with rainy summers and dry winters, and annual averages of $24.1^{\circ} \mathrm{C}$ temperature and $1521 \mathrm{~mm}$ rainfall. August is the driest month with an average of $24 \mathrm{~mm}$, while January is the rainiest with an average of $279 \mathrm{~mm}$ (CLIMATEDATA.ORG, 2021).

Since there were no replication of protected environments, each one comprised an experiment. Both experiments were carried out in fully randomized designs, with seven replications and five plants per plot. Data were first subjected to individual variance analysis for benches. Then, mean squared residues (MSR) and joint analysis of experiments were performed (Banzatto \& Kronka, 2013) in a factorial $2 \times 2$ (2 protected environments x 2 cultivation benches with and without reflective material). The results were subjected to analysis of variance, and means compared by the F-test at $5 \%$ probability.

Rubber tree seeds were collected on February 23, 2018 in the Center of Rubber Tree and Agroforestry Systems (IAC) in Votuporanga city, São Paulo State, Brazil. After collection, they were sown in a seedbed filled with sand to produce seedlings. The seedlings were transferred to $1.8-\mathrm{L}$ $(15.0 \times 25.0 \mathrm{~cm})$ polyethylene bags 29 days after sowing.

Containers were filled with substrate containing $10 \%$ bovine manure, 30\% embankment soil, $40 \%$ superfine vermiculite, $10 \%$ medium vermiculite, and $10 \%$ sand. They were then placed on suspended benches, as recommended by the Normative Instruction n. 29 (Brasil, 2009). For bovine manure, the following characteristics: $\mathrm{pH}$ in water, organic matter $\left(\mathrm{g} \mathrm{kg}^{-1}\right)$, carbon and nitrogen ratio, total nitrogen $\left(\mathrm{g} \mathrm{kg}^{-1}\right)$, phosphorus $\left(\mathrm{mg} \mathrm{kg}^{-1}\right)$, potassium ( $\mathrm{mg} \mathrm{kg}^{-}$ $\left.{ }^{1}\right)$, calcium $\left(\mathrm{mg} \mathrm{kg}^{-1}\right)$, magnesium $\left(\mathrm{mg} \mathrm{kg}^{-1}\right)$, sulfur ( $\mathrm{mg} \mathrm{kg}^{-}$ $\left.{ }^{1}\right)$, copper $\left(\mathrm{mg} \mathrm{kg}^{-1}\right)$, and iron $\left(\mathrm{mg} \mathrm{kg}^{-1}\right)$ were $5.8,200.0$, $12: 1,9.0,1300.0,800.0,3000.0,1000.0,200.0$, 18.0, 12103.0, 204.4, 53.0, and 624.0, respectively. For embankment soil, they were $4.4,5.0$, non-determined, nondetermined, 9.0, 39.0, 320.0, 72.0, 5.4, 0.4, 30.0, 8.8, 0.3, and 0.0 , respectively. The soil used was collected from the surface layer of an embankment with $1.10 \mathrm{~m}$ profile.

Fertilization was carried out monthly with $0.5 \mathrm{~g}$ NPK (4-20-20) per plant until July, increasing to 0.6 g NPK (420-20) per plant in the following months until the end of the experiment. Micronutrients were also supplied by applying Conmicros $®$ Standard at $0.025 \mathrm{~g}$ per $10 \mathrm{~L}$ water $(20 \mathrm{~mL}$ per plant), which contains iron $(7.26 \%)$, copper $(1.82 \%)$, zinc $(0.73 \%)$, manganese $(1.82 \%)$, boron $(1.82 \%)$, molybdenum $(0.36 \%)$, and nickel $(0.36 \%)$.

The following doses of active ingredients were applied: $0.4 \mathrm{~g} \mathrm{~L} \mathrm{~L}^{-1}$ thiophanate-methyl, 3,0 $\mathrm{mL} \mathrm{L}^{-1}$ chlorothalonil, $0.67 \mathrm{ml} \mathrm{L}^{-1}$ trifloxystrobin, tebuconazole and neem oil $\left(12 \mathrm{~mL} \mathrm{~L}^{-1}\right)+0.3 \mathrm{~g} \mathrm{~L}^{-1}$ abamectin.

Plant height $(\mathrm{PH}, \mathrm{cm})$ and neck diameter $(\mathrm{ND}, \mathrm{mm})$ were measured at 83,128, 165, 207, and 236 days after sowing (DAS), which were designated PH83, PH128, PH165, PH207, PH236, ND83, ND128, NC165, ND207, and ND236, respectively. Stem diameter was also measured at $5 \mathrm{~cm}$ from the substrate (SD, mm), at 207 and $236 \mathrm{DAS}$, namely SD207 and SD236, respectively.

Shoot dry matter (SDM) and root system dry matter (RDM) were also measured at $236 \mathrm{DAS}$, and subsequently added to obtain the total dry matter (TDM) values.

The ratios shoot and root dry matter (SRDM) and seedling height and neck diameter (SHND), and the Dickson quality index (DQI), were estimated at 236 DAS.

Plant height was measured from substrate surface to plant apex by a millimeter ruler. Neck diameter was measured at substrate level and stem diameter at $5 \mathrm{~cm}$ from substrate surface, using a digital caliper. For dry matter measurements, seedlings were kept in an air circulation oven at $65^{\circ} \mathrm{C}$ for 72 hours, and then weighed in a precision scale.

Data on air temperature $\left(\mathrm{T}\right.$, in $\left.{ }^{\circ} \mathrm{C}\right)$, relative humidity

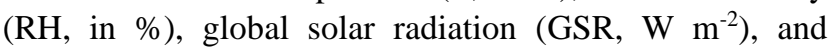
photosynthetically active radiation (PAR, in $\mu \mathrm{mol} \mathrm{m} \mathrm{m}^{-2} \mathrm{~s}^{-1}$ ) were measured. The variables $\mathrm{T}, \mathrm{RH}$, and PAR were collected from meteorological stations installed inside and at the center of each protected environment, and external data were collected were collected from station A742 Cassilândia (INMET). GSR was measured between 9 am and 4 pm (Brasília local time). PAR was manually measured daily, using a portable digital pyranometer (Apogee) at 10 am local time, which corresponds to 11 am in Brasília local time, on clear sky days (without cloudiness).

Each month of collection, from March to October, was considered a block (one repetition) to statistically compare the environmental data (micrometeorological variables). Data on temperature $\left(\mathrm{T}^{\circ} \mathrm{C}\right)$, relative humidity (RH\%), global solar radiation (GSR), and incident photosynthetically active radiation (PAR) were evaluated in a randomized block design, with eight replications. Reflected photosynthetically active radiation (RPAR) was evaluated in a randomized block and $2 \times 2$ factorial scheme (two 
environments $\mathrm{X}$ two cultivation benches, with and without reflective material), with eight replications. The results were subjected to analysis of variance. Means were compared by F-test in case of two treatments, and by the Tukey's test in case of more treatments, both at $5 \%$ probability.

\section{RESULTS AND DISCUSSION}

Figure 1 shows that air temperature and relative humidity were similar among the months of evaluation, both in protected and external environments.

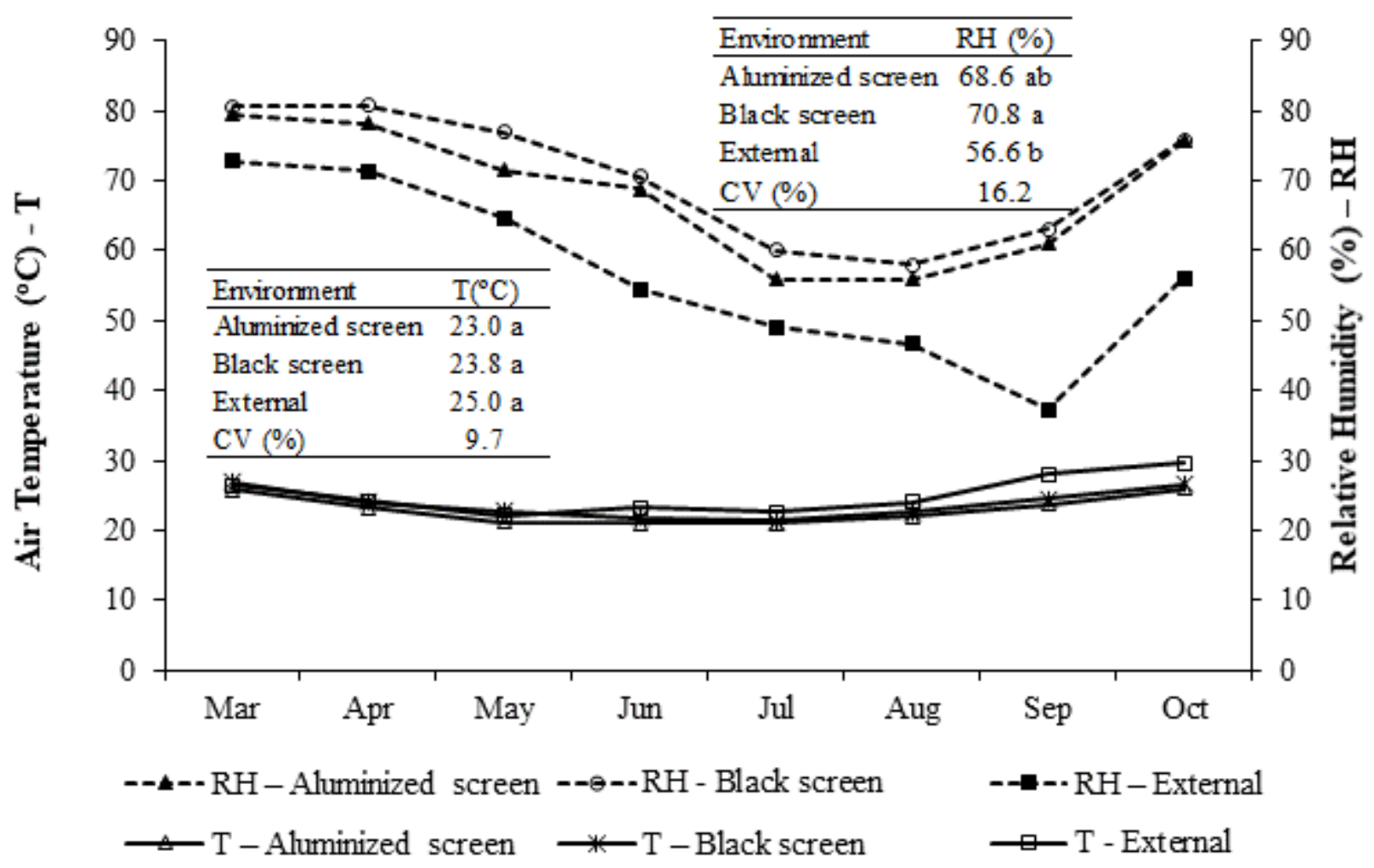

FIGURE 1. Air temperature $\left(\mathrm{T},{ }^{\circ} \mathrm{C}\right)$ and relative humidity $(\mathrm{RH}, \%)$ in the protected environments and external environment. Means followed by the same lowercase letter in the column do not differ by the Tukey's test at $5 \%$ probability. CV $=$ coefficient of variation.

Average temperatures did not differ among protected environments and external environment, but average relative humidity in the black screen environment was higher than that in the external environment. This is because a micro sprinkler irrigation system was used inside the protected environment (Figure 1).
Global solar radiation (GSR) and incident photosynthetically active radiation (PAR) were different between both protected environments along the months of evaluation (Figure 2). 


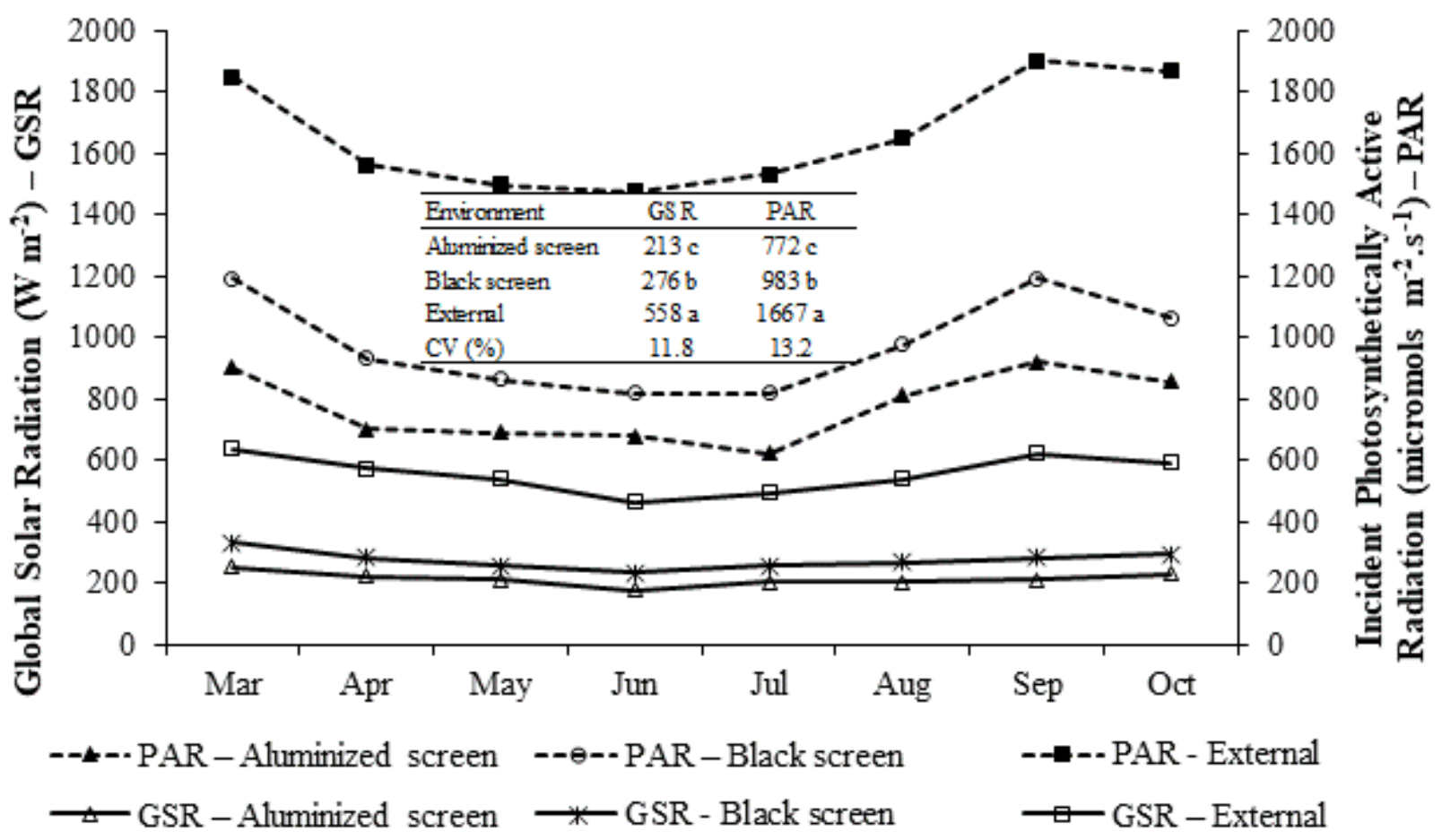

FIGURE 2. Global solar radiation $\left(\mathrm{GSR}, \mathrm{Wm}^{-2}\right.$ ) and photosynthetically active radiation (PAR, micromol. $\left.\mathrm{m}^{-2} \mathrm{~s}^{-1}\right)$ in the protected environments and external environment. Means followed by the same lowercase letter in the column do not differ by the Tukey's test at $5 \%$ probability. $\mathrm{CV}=$ coefficient of variation.

Averages of GSR and PAR were higher in the black screen environment compared to those in the aluminized screen one, and both were lower than those in the external environment (Figure 2). Therefore, solar radiation (global and photosynthetically active) was the most influencing factor on plant environment and plant growth differentiation in the protected environments.

Incident GSR in the black and aluminized screen environments corresponded to 49.4 and $38.2 \%$ of the GSR in the external environment, respectively. Moreover, incident PAR in the black and aluminized screen environments corresponded to 59.0 and $46.3 \%$ of the external PAR. In both environments, PAR was, on average, 20\% higher than the GSR. Both GSR and incident PAR were, on average, $12 \%$ higher in the black screen environment compared to the aluminized screen one (Figure 2).

PAR reflected in the environments and in the cultivation benches with reflective material showed an interaction between factors (Figure 3).

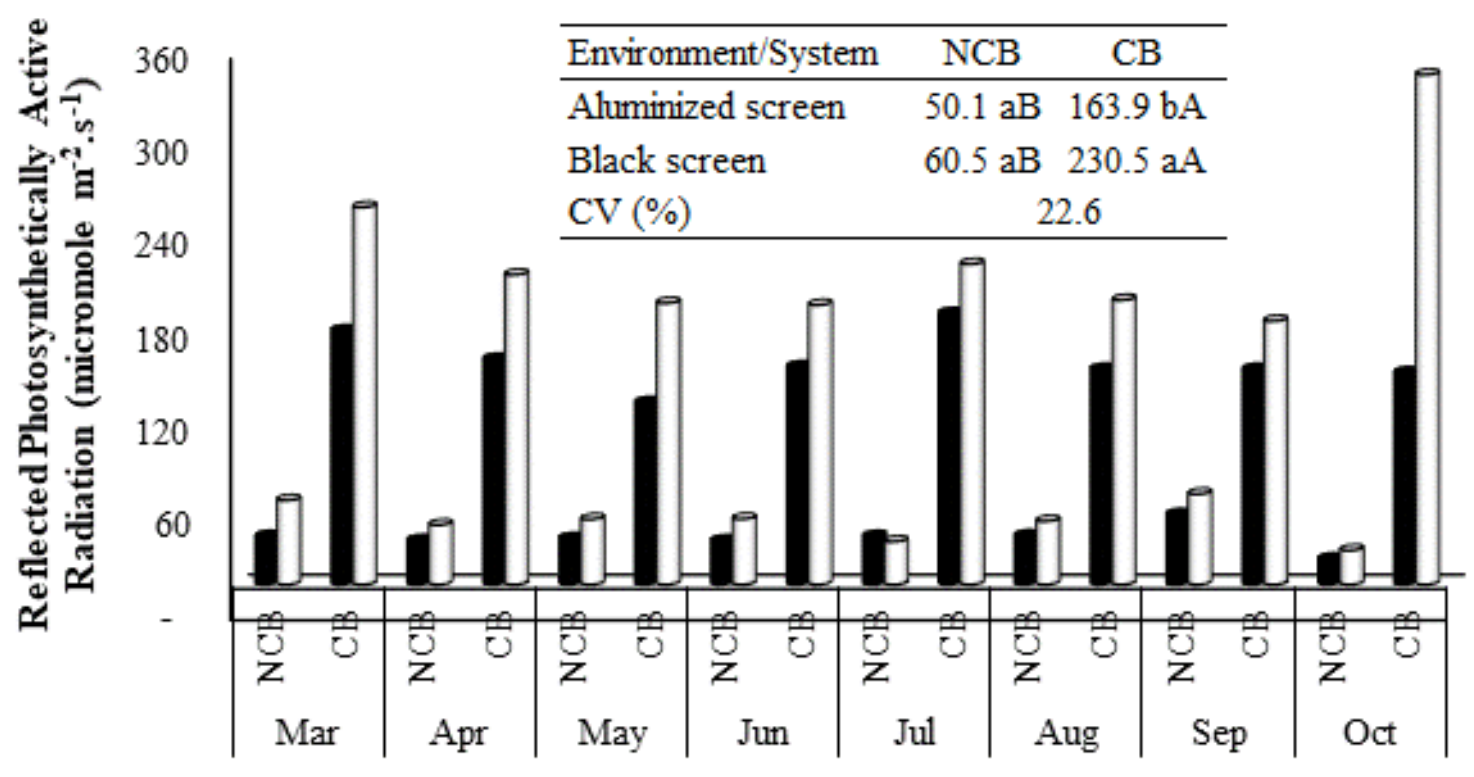

- Aluminized screen

口Black screen

FIGURE 3. Photosynthetically active radiation (PAR) reflected in the cultivation bench with (CB) and without (NCB) reflective material in the protected environments. Means followed by the same lowercase letter in the column and uppercase letter in the row for each factor do not differ by the F-test at $5 \%$ probability. $\mathrm{CV}=$ coefficient of variation. 
PAR reflected in the NCB system showed no difference between both environments, but it was higher for the $\mathrm{CB}$ system in the black screen environment. In both environments, reflected PAR of the $\mathrm{CB}$ system was higher than that of the NCB (Figure 3).
Of all the factors evaluated in this study, the ratio between the highest and lowest mean squared residues of the individual variance analysis did not exceed 7:1 (Table 1), which allowed a joint analysis of the experiments (Banzatto \& Kronka, 2013) to compare both protected environments.

TABLE 1. Mean squared residue and ratio between the highest and lowest mean squared residues (MSR) for the variables seedling height (SH) at 83, 128, 165, 207, and 236 DAS (SH83, SH128, SH165, SH207, and SH236 respectively), neck diameter (ND) at 83, 128, 165, 207, and 236 DAS (ND83, ND128, ND165, ND207 and ND236, respectively), stem diameter (SD) at 5 $\mathrm{cm}$ at 207 and 236 DAS (SD207 and SD236, respectively), shoot dry matter (SDM), root dry matter (RDM), total dry matter (TDM), shoot and root dry matter ratio (SRDM), seedling height and neck diameter ratio (SHND), and Dickson quality index (DQI).

\begin{tabular}{lccccccccc}
\hline Environment & SH83 & SH128 & SH165 & SH207 & SH236 & SD207 & SD236 & SD83 & SD128 \\
\hline Black Screen & 11.27 & 9.75 & 12.04 & 9.74 & 11.39 & 0.32 & 0.34 & 0.12 & 0.23 \\
Aluminized Screen & 17.26 & 17.07 & 24.29 & 13.79 & 17.58 & 0.22 & 0.22 & 0.16 & 0.09 \\
(MSR) & 1.5 & 1.8 & 2.0 & 1.4 & 1.5 & 1.5 & 1.5 & 1.4 & 2.5 \\
\hline Environment & ND165 & ND207 & ND236 & SDM & RDM & TDM & SHND & SRDM & DQI \\
\hline Black Screen & 0.14 & 0.29 & 0.62 & 2.11 & 1.53 & 6.85 & 0.68 & 0.07 & 0.16 \\
Aluminized Screen & 0.06 & 0.17 & 0.22 & 1.27 & 0.67 & 3.40 & 0.50 & 0.04 & 0.04 \\
(MSR) & 2.4 & 1.7 & 2.9 & 1.7 & 2.3 & 2.0 & 1.3 & 1.7 & 4.0 \\
\hline
\end{tabular}

Statistical breakdown of treatments showed no interaction between the factors $(\mathrm{E} \times \mathrm{S})$ protected environment and production system (CB and $\mathrm{NCB})$ for ND165 and ND207, SD236, and for SDM, RDM, TDM, and DQI at 236 DAS. There was also no interaction between both factors for seedling height (SH83, SH128, SH165, SH207, SH236), stem diameter (SD83, SD128, SD236), neck diameter (ND207, SHND), and RDM; therefore, significances were only verified for each independent factor (Table 2).

TABLE 2. Analysis of variance for seedling height (SH) at 83, 128, 165, 207, and 236 DAS (SH83, SH128, SH165, SH207 and SH236, respectively), neck diameter (ND) at 83, 128 , 165, 207, and 236 DAS (ND83, ND128, ND165, ND207, and ND236, respectively), stem diameter (SD) at $5 \mathrm{~cm}$ at 207 and 236 DAS (SD207 and SD236, respectively), shoot dry matter (SDM), root dry matter (RDM), total dry matter (TDM), shoot and root dry matter ratio (SRDM), seedling height and neck diameter ratio (SHND), and Dickson quality index (DQI).

\begin{tabular}{cccccccccc}
\hline Treatment & SH83 & SH128 & SH165 & SH207 & SH236 & ND83 & ND128 & ND165 & ND207 \\
\hline Environment (E) & $\mathrm{Ns}$ & $\mathrm{ns}$ & $\mathrm{ns}$ & $\mathrm{ns}$ & $\mathrm{Ns}$ & $* *$ & $* *$ & $* *$ & $* *$ \\
System (S) & $*$ & $* *$ & $\mathrm{~ns}$ & $* *$ & $* *$ & $* *$ & $* *$ & $* *$ & $* *$ \\
E X S & $\mathrm{ns}$ & $\mathrm{ns}$ & $\mathrm{ns}$ & $\mathrm{ns}$ & $\mathrm{Ns}$ & $\mathrm{Ns}$ & $\mathrm{ns}$ & $*$ & $*$ \\
\hline Treatments & $\mathrm{ND} 236$ & $\mathrm{SD} 207$ & $\mathrm{SD} 236$ & $\mathrm{SDM}$ & $\mathrm{RDM}$ & $\mathrm{TDM}$ & SHND & SRDM & DQI \\
\hline Environment (E) & $* *$ & $* *$ & $* *$ & $* *$ & $\mathrm{Ns}$ & $* *$ & $* *$ & Ns & $* *$ \\
System (S) & $* *$ & $* *$ & $* *$ & $* *$ & $* *$ & $* *$ & $\mathrm{~ns}$ & $\mathrm{Ns}$ & $* *$ \\
E X S & $\mathrm{ns}$ & $\mathrm{ns}$ & $*$ & $* *$ & $*$ & $* *$ & $\mathrm{~ns}$ & $\mathrm{Ns}$ & $* *$ \\
\hline
\end{tabular}

* Significant at $5 \%$ probability; $* *$ significant at $1 \%$ probability, ns = not significant.

No significant differences were observed between both cultivation environments for plant height, with both favoring growth of rubber tree seedlings (Table 3). 
TABLE 3. Seedling heights at 83, 128, 165, 207, and 236 DAS (SH83, SH128, SH165, SH207, and SH236 in cm, respectively), neck diameter at 83, 128, and 236 DAS (ND83, ND128, ND236 in mm, respectively), stem diameter at $5 \mathrm{~cm}$ at 207 DAS (SD207 in $\mathrm{mm}$ ), seedling height and neck diameter ratio (SHND), and shoot and root dry matter ratio (SRDM) of rubber tree rootstock seedlings in two protected environments (AS: aluminized screen; BS: black screen) and cultivation systems of benches with $(\mathrm{CB})$ and without $(\mathrm{NCB})$ reflective material.

\begin{tabular}{lccccccccccc}
\hline Environment & SH83 & SH128 & SH165 & SH207 & SH236 & SH83 & ND128 & ND236 & SD207 & SHND & SRDM \\
\hline AS & $33.5 \mathrm{a}$ & $38.0 \mathrm{a}$ & $43.9 \mathrm{a}$ & $52.0 \mathrm{a}$ & $56.0 \mathrm{a}$ & $3.9 \mathrm{~b}$ & $5.0 \mathrm{~b}$ & $4.5 \mathrm{~b}$ & $4.5 \mathrm{~b}$ & $8.6 \mathrm{a}$ & $1.5 \mathrm{a}$ \\
BS & $34.3 \mathrm{a}$ & $38.9 \mathrm{a}$ & $46.9 \mathrm{a}$ & $52.5 \mathrm{a}$ & $57.2 \mathrm{a}$ & $4.3 \mathrm{a}$ & $5.5 \mathrm{a}$ & $7.4 \mathrm{a}$ & $5.3 \mathrm{a}$ & $7.9 \mathrm{~b}$ & $1.6 \mathrm{a}$ \\
\hline System & SH83 & SH128 & SH165 & SH207 & SH236 & ND83 & ND128 & ND236 & ND207 & SHND & SRDM \\
\hline CB & $35.8 \mathrm{a}$ & $40.61 \mathrm{a}$ & $46.8 \mathrm{a}$ & $55.8 \mathrm{a}$ & $61.4 \mathrm{a}$ & $4.4 \mathrm{a}$ & $5.56 \mathrm{a}$ & $7.6 \mathrm{a}$ & $5.4 \mathrm{a}$ & $8.1 \mathrm{a}$ & $1.6 \mathrm{a}$ \\
NCB & $32.0 \mathrm{~b}$ & $36.21 \mathrm{~b}$ & $44.0 \mathrm{a}$ & $48.7 \mathrm{~b}$ & $51.9 \mathrm{~b}$ & $3.9 \mathrm{~b}$ & $4.87 \mathrm{~b}$ & $6.2 \mathrm{~b}$ & $4.4 \mathrm{~b}$ & $8.4 \mathrm{a}$ & $1.6 \mathrm{a}$ \\
\hline CV $(\%)$ & 11.1 & 9.5 & 9.4 & 6.6 & 6.7 & 9.1 & 7.8 & 9.3 & 10.7 & 9.4 & 15.3 \\
\hline
\end{tabular}

Means followed by the same lowercase letter in the column for each variable do not differ by the F-test at $5 \%$ probability. CV = coefficient of variation.

Cultivation benches covered with reflective material promoted increase in height of rubber tree seedlings (Table $3)$. Therefore, light reflectance of the material provided more favorable conditions for photosynthesis by increasing availability of PAR (Figure 3), increased use of light by plants, and therefore their growth.

The screen types used to cover the protected environments (black monofilament and aluminized screens with $30 \%$ and $35 \%$ shading respectively) promoted a similar growth effect on rubber tree seedlings. These results are in line with those of Vieira et al. (2016), who found that the use of Sombrite ${ }^{\circledR}$ and Aluminet ${ }^{\circledR}$ screens, both with $50 \%$ shading, contributed positively to production of rubber-tree rootstocks clone GT1 compared to direct sunlight.

The higher rubber tree seedlings in systems with reflective material shows a better distribution of PAR and its use by plants. This corroborates the findings of Salles et al. (2017), who observed greater jambolan seedlings on benches with reflective material in screened environments with 30 and $50 \%$ shading. Larger passion fruit seedlings were obtained in a system with benches covered with reflective material (mirror), which improved the use of radiation emitted by plants (Santos et al., 2017).

Neck (ND83) and stem (SD207) diameters were larger in the black screen environment with $30 \%$ shading compared to those in the aluminized environment with 35\% shading. The use of reflective material on the cultivation benches proved to benefit plants, as it favored stem and neck diameter increases (Table 3). PAR reflectance increased amount of radiation (Figure 2) and improved its use by plants, thus resulting in the larger diameters (Table 3). These results corroborate the findings of Salles et al. (2017), who also observed larger diameters in jambolan seedlings produced on benches with reflective material (Aluminet ${ }^{\circledR}$ ). However, such material did not positively influence production of papaya (Cabral et al., 2020) and baruzeiro (Costa et al., 2020c) seedlings. The use of reflective material enabled a redistribution of radiation to the abaxial part of seedling leaves, enhancing its uptake by plant photosynthetic structure and enlarging plant diameters.

Shoot and root dry matter ratio (RDM) showed a suitable phytomass partitioning, with values ranging from 1.51 to 1.63 and no differences between environments and systems. The best seedling height and diameter ratio (SHND) was found in the black screen environment, which was lower than those found in the aluminized screen experiment, showing plants less prone to etiolation (Table 3 ).

There was interaction between protected environments and cultivation systems at 165 and 207 DAS for neck diameters (ND165 and ND207, respectively). Therefore, the use of reflective material favored increases in seedling diameter (Table 4) in both protected environments. Thus, such technology can improve rootstock quality by redistributing PAR (Figure 3) and hence increasing photosynthesis. By comparing environments, the black screen promoted plants with a larger neck diameter at 165 and 207 DAS in both bench types (Table 4). 
TABLE 4. Interaction between protected environment and cultivation system with (CB) and without (NCB) reflective material for neck diameter at $165(\mathrm{ND} 165, \mathrm{~mm})$ and $207(\mathrm{ND} 207, \mathrm{~mm})$ DAS, stem diameter at $5 \mathrm{~cm}$ at $236(\mathrm{SD} 236, \mathrm{~mm})$ DAS, for shoot dry matter (SDM, g), root dry matter (RDM, g), total dry matter (TDM, g), and the Dickson Quality Index (DQI) of rubber tree rootstock seedlings.

\begin{tabular}{|c|c|c|c|c|c|c|c|c|}
\hline & \multicolumn{2}{|c|}{ ND165 } & \multicolumn{2}{|c|}{ ND207 } & \multicolumn{2}{|c|}{ SD236 } & \multicolumn{2}{|c|}{ SDM } \\
\hline & $\mathrm{CB}$ & NCB & $\mathrm{CB}$ & NCB & $\mathrm{CB}$ & NCB & $\mathrm{CB}$ & NCB \\
\hline AS & $5.8 \mathrm{aB}$ & $5.2 \mathrm{bB}$ & $6.2 \mathrm{aB}$ & $5.6 \mathrm{bA}$ & $5.4 \mathrm{aB}$ & $4.7 \mathrm{bA}$ & $6.84 \mathrm{aB}$ & $4.48 \mathrm{bA}$ \\
\hline BS & $6.8 \mathrm{aA}$ & $5.8 \mathrm{bA}$ & $7.4 \mathrm{aA}$ & $5.9 \mathrm{bA}$ & $6.8 \mathrm{aA}$ & $5.1 \mathrm{bA}$ & $9.95 \mathrm{aA}$ & $4.44 \mathrm{bA}$ \\
\hline \multirow[t]{3}{*}{$\mathrm{CV}(\%)$} & \multicolumn{2}{|c|}{5.3} & \multicolumn{2}{|c|}{7.7} & \multicolumn{2}{|c|}{9.6} & \multicolumn{2}{|c|}{20.2} \\
\hline & \multicolumn{2}{|c|}{ RDM } & \multicolumn{2}{|c|}{ TDM } & \multicolumn{2}{|c|}{ DQI } & & \\
\hline & $\mathrm{CB}$ & $\mathrm{NCB}$ & $\mathrm{CB}$ & NCB & $\mathrm{CB}$ & NCB & & \\
\hline AS & $4.52 \mathrm{aB}$ & $3.03 \mathrm{bA}$ & $11.36 \mathrm{aB}$ & $7.51 \mathrm{bA}$ & $1.12 \mathrm{aB}$ & $0.74 \mathrm{bA}$ & & \\
\hline BS & $6.24 \mathrm{aA}$ & $2.82 \mathrm{bA}$ & $16.19 \mathrm{aA}$ & $7.26 \mathrm{bA}$ & $1.78 \mathrm{aA}$ & $0.76 \mathrm{bA}$ & & \\
\hline $\mathrm{CV}(\%)$ & \multicolumn{2}{|c|}{25.2} & \multicolumn{2}{|c|}{21.4} & \multicolumn{2}{|c|}{28.7} & & \\
\hline
\end{tabular}

Means followed by the same uppercase letter in the column and lowercase letter in the line for each factor do not differ by the F-test at $5 \%$ probability. AS = aluminized screen, $\mathrm{BS}=$ black screen.

In both environments, the use of reflective material favored increases in SD236, SDM, RDM, TDM, and DQI (Table 4). This, therefore, highlights that the use of reflective material on cultivation benches improves quality of seedlings for rubber tree rootstocks by enhancing PAR conditions (Figure 3), which increases photosynthesis and hence plant growth. These findings are in line with Santos et al. (2017), Salles et al. (2017), Mortate et al. (2019), Cabral et al. (2020), and Costa et al. (2020 a, b, c).

When comparing both environments without reflective material, our results are in line with those of Vieira et al. (2016). These authors verified that Sombrite ${ }^{\circledR}$ and Aluminet ${ }^{\circledR}$ screens, both with $50 \%$ shading, did not differ from each other and both contributed to formation of rubber tree rootstocks with larger root systems, which was superior to those from full sun environment. In turn, our findings for rubber tree are different from those for papaya trees, wherein, regardless of the substrate, the aluminized screen increased leaf, shoot, root, and total dry matters when a container with higher substrate volume was used (Costa et al., 2009).
When comparing the cultivation environments, the benches with reflective material were observed to produce seedlings with higher ND, SDM, RDM, TDM, and DQI with the black screen, however, the environments did not differ for these variables on the benches without reflective material (Table 4).

When the reflective material was used, both black and aluminized screens allowed a better distribution and use of PAR (Figure 2) by plants. The quality of the seedlings produced was higher (Tables 3 and 4), showing greater growth in height, diameter, and phytomass accumulation due to an optimization in photosynthetic process. In short, the use of reflective material on cultivation benches had a positive effect on production of rubber rootstock seedlings of the clone GT1.

On average, shoot and root phytomass distribution had a proportion of 60 to $40 \%$, that is, $60 \%$ shoot and $40 \%$ root system, regardless of the cultivation environment and use of reflective material on benches (Figure 4).

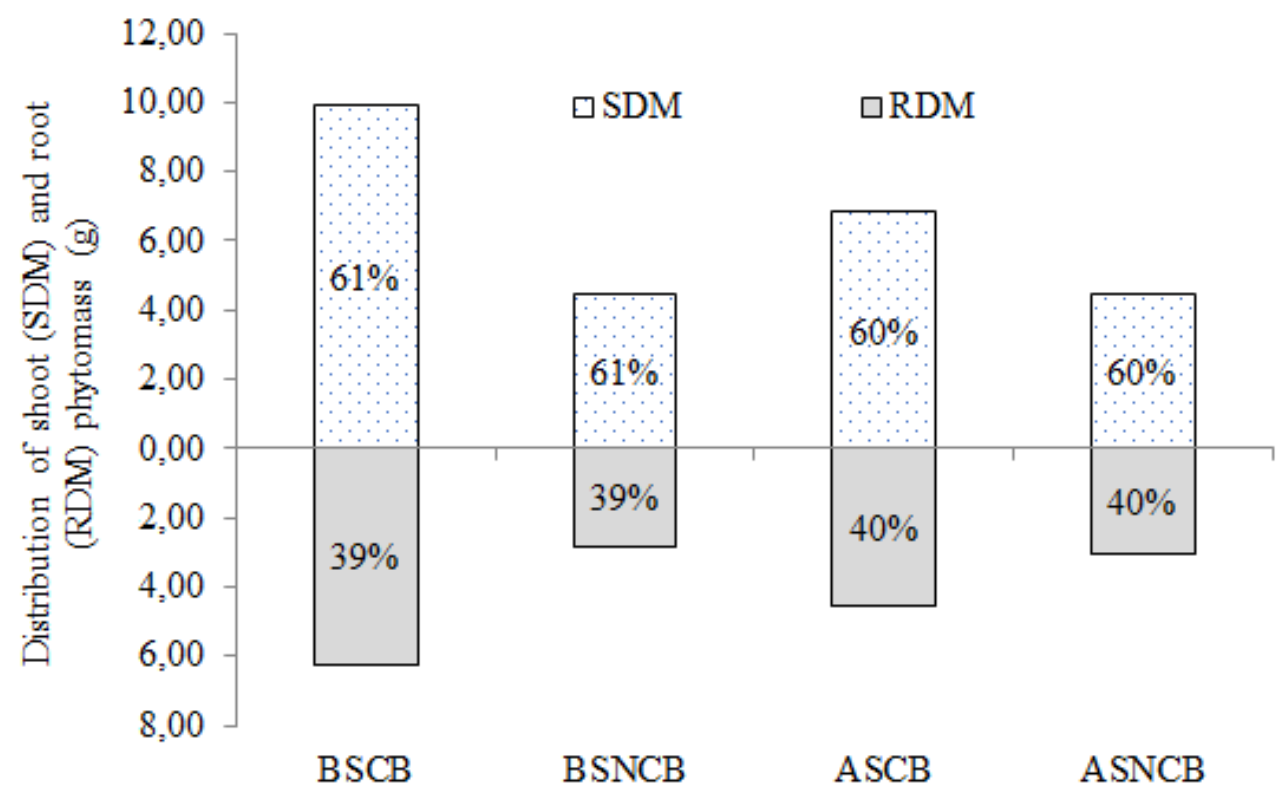

FIGURE 4. Distribution of shoot (SDM) and root (RDM) phytomass in the black screen environment with reflective material (BSCB), black screen environment without reflective material (BSNCB), aluminized screen environment with reflective material (ASCB), and aluminized screen environment without reflective material (ASNCB). 
When applied to rubber tree seedling formation, our ambience treatments (protected environments and reflective material use) did not change partitioning of shoot and root photoassimilates, remaining $40 \%$ in roots and $60 \%$ in shoot. This corroborates the results of Pereira et al. (2019) also in rubber tree seedlings of the GT1 clone, with apical pruning treatments. In testing substrates for GT1, PR255, and RRIM600 clones, Vieira et al. (2016) obtained the same proportion, whereas Silva et al. (2020) reported $34 \%$ in roots and $66 \%$ in shoot. Our findings show that the use of reflective material provides robust root systems, improving quality of seedlings and their settling in the field.

\section{CONCLUSIONS}

Solar radiation (global and photosynthetically active) is one of the major micrometeorological factors influencing plant environment and growth differentiation.

The use of reflective material on cultivation benches had a positive effect on formation rubber rootstock seedlings of the clone GT1, regardless of the cultivation environment, producing seedlings with robust root systems and better quality.

The use of reflective material on benches in the black screen environment provided formation of better rubber tree rootstock seedlings of the clone GT1.

\section{ACKNOWLEDGEMENTS}

The authors thank the Foundation for Support to the Development of Teaching, Science, and Technology of Mato Grosso do Sul State - FUNDECT (FUNDECT/ CNPq/ PRONEM - MS, process \# 59/300.116/2015 - $\mathrm{n}^{\circ}$ FUNDECT 080/2015), the Graduate Program in Agronomy of the State University of Mato Grosso do Sul for the study opportunity, the Center for Rubber Tree and Agroforestry Systems of the Agronomic Institute of Campinas (IAC) in Votuporanga - SP, and the Brazilian Council for Scientific and Technological Development (CNPq).

\section{REFERENCES}

Banzatto DA, Kronka SN (2013) Experimentação agrícola. Jaboticabal, Funep.

Cabral RC, Vendruscolo EP, Martins MB, Zoz T, Costa E, Silva AG (2020) Material reflectante en bancos de cultivo y paja de arroz sobre el sustrato en la producción de plántulas de papaya. Revista Mexicana de Ciencias Agrícolas 11(8): 1713-1723. DOI:

https://doi.org/10.29312/remexca.v11i8.2481

Brasil. Ministério da Agricultura, Pecuária e Abastecimento. Instrução Normativa $n^{\circ} 29$, de 5 de Agosto de 2009. Aprova as normas para a produção de sementes e mudas de seringueiro (Hevea spp.). Diário Oficial da União, Brasília, 6 ago. 2009. Seção 1, p. 5.

Climate-Data.Org. Climate-Data.org > América do Sul > Brasil > Mato Grosso do Sul > Cassilândia. 2021. Available: http://pt.climate-data.org/location/43419/. Accessed May 14, 2021.
Conforto EC; Bittencourt Júnior NS, Scaloppi Júnior EJ, Moreno RM (2011) Comparação entre folhas sombreadas de sete clones adultos de seringueira. Revista Ceres 58(1): 29-34. DOI: http://dx.doi.org/10.1590/S0034737X2011000100005.

Costa E, Curi TMRC, Figueiredo T, Binotti FFS, Cardoso ED (2017) Kale seedlings production in different substrates, cell volumes and protected environments. Engenharia Agrícola 37(1): 46-53. DOI: http://dx.doi.org/10.1590/18094430-eng.agric.v37n1p46-53/2017.

Costa E, Lopes TC, Silva AG, Zoz T, Salles JS, Lima AHF, Binotti FFS, Vieira GHC (2020b) Reflective material in the production of Dipteryx alata seedlings. Research, Society and Development $9(8)$ : e430985428. DOI: https://doi.org/10.33448/rsd-v9i8.5428

Costa E, Martins MB, Vedruscolo EP, Silva AG, Zoz T, Binotti FFS, Witt TW, Seron CC (2020a) Greenhouses within the Agricultura 4.0 interface. Revista Ciência Agronômica 51(5): e20207703. DOI:

http://ccarevista.ufc.br/seer/index.php/ccarevista/article/vie w/7703

Costa E, Santos LCR, Vieira LCR (2009) Produção de mudas de mamoeiro utilizando diferentes substratos, ambientes de cultivo e recipientes. Engenharia agrícola 29(4): 528-537. DOI: http://dx.doi.org/10.1590/S010069162009000400003 .

Costa GGS, Costa E, Silva EM, Borges RS, Binotti FFS, Vieira GHC, Souza AFGO (2020 c) Shading level, reflective material, and seeding depth on the growth of baru seedlings. Agricultural Engineering International: CIGR Journal, 22(4): 83-92. Available:

https://cigrjournal.org/index.php/Ejounral/article/view/578 5 Accessed: Fev 25, 2021.

Coutinho EF, Franchini ER, Camelatto D, Ulguim EB (2005) Relação entre poda verde e o uso de material refletivo com qualidade de pêssegos' Eldorado'. Pelotas, Embrapa Clima Temperado, 19 p. Available: https://www.infoteca.cnptia.embrapa.br/infoteca/bitstream/ doc/744939/1/documento134.pdf

Cruz FCR, Andrade LA, Feitosa RC (2016) Produção de mudas de umbuzeiro (Spondia tuberose Arruda Câmara) em diferentes substratos e tamanho de recipientes. Ciência Florestal 26(1): 69-80. DOI: http://dx.doi.org/10.5902/1980509821092.

Mortate RK, Costa E, Vieira GHC, Sousa HF, Borges RS, Barbosa WFS, Costa GGS (2019) Levels of shading and reflective material in benches for Schizolobium amazonicum seedlings. Journal of Agricultural Science 11(5): 485-495. DOI: https://doi.org/10.5539/jas.v11n5p485

Pereira AC, Scaloppi Junior EJ, Costa E, Martins GLM, Vieira NCS (2019) Efeito da poda apical nos atributos morfofisiológicos do porta-enxerto clonal de seringueira GT1. Ciência Florestal 29(2): 900-912. DOI: https://doi.org/10.5902/1980509824542 
Salles JS, Lima AHF, Costa E (2017) Mudas de jambolão sob níveis de sombreamento, bancadas refletoras e profundidade de semeadura. Revista de Agricultura Neotropical 4(5): 110-118. DOI:

https://doi.org/10.32404/rean.v4i5.2181

Santos ELL, Silva AK, Curi TMRC, Costa E, Jorge MHA. (2016). Production of 'Formosa' papaya seedlings in different protected environments and organic substrates. Revista de Agricultura Neotropical 3(2): 16-24. DOI: https://doi.org/10.32404/rean.v3i2.1107

Santos TV, Lopes TC, Silva AG, Paula RCM, Costa E, Binotti FFS (2017) Produção de mudas de maracujá amarelo com diferentes materiais refletores sobre bancada. Revista de Agricultura Neotropical 4(4): 26-32. https://doi.org/10.32404/rean.v4i4.178
Silva AG, Costa E, Pereira TCC, Binotti FFS, Scaloppi Junior EJ, Zoz T (2020) Quality of rubber tree rootstock seedlings grown in protected environments and alternative substrates. Acta Scientiarum-Agronomy 42: e43469. DOI: http://dx.doi.org/10.4025/actasciagron.v42i1.43469

Vieira NCS, Maruyama WI, Costa E, Dias PMD, Pereira A (2016) Clones, substrates and environments for seedlings of Rubber tree rootstocks. Engenharia Agrícola 36(5): 749-759. DOI: https://doi.org/10.1590/1809-4430Eng.Agric.v36n5p749-759/2016

Wang LJ, Jiang WB, Huang BJ (2004) Promotion of 5aminolevulinic acid on photosynthesis of melon (Cucumis melo) seedlings under low light and chilling stress conditions. Physiologia Plantarum 121(2): 258-264. DOI: https://doi.org/10.1111/j.0031-9317.2004.00319.x 